\title{
Florensky and Kant - the Metaphysics of Faith vs the Metaphysics of Reason*
}

\author{
Vladimir Belov \\ Peoples' Friendship University of Russia \\ Moscow, Russia \\ E-mail: belovvn@rambler.ru
}

\author{
Julia Karagod \\ Peoples' Friendship University of Russia \\ Moscow, Russia \\ E-mail: karagod_yug@pfur.ru
}

\begin{abstract}
The article reviews the criticism of philosophical position of I. Kant by the Russian religious philosopher Pavel Florensky. The sharpness of such criticism is explained by the Russian philosopher's recognition in Kant not just of the assertion of power of reason as opposed to faith, but the assertion of the power of mind at the cost of faith. The religious thinker and priest in one person, he was most acutely able to feel the depth of transformation of the believing mind and its aberration that inevitably follows such a transformation.
\end{abstract}

Keywords-Kant; Russian religious philosophy; Pavel Florensky; antinomies; idealism; Platonism

\section{INTRODUCTION}

There are obvious contradictions and inconsistencies about Kant and the Russian religious philosophy. On the one hand, a great many Russian religious philosophers had come to the religious philosophy from Marxism owing to Kant, but as religious philosophers, perhaps, no one had been criticized as much as Kant. On the one hand, the Russian philosophers emphasize Kant's enduring merit in substantiating the autonomy of morality (V. Solovyov), in asserting the antinomy of the human mind (P. Florensky); on the other hand, they call him the greatest seducer and tempter for a thinking person.

The article cannot break up in detail all the nuances of this serious and broad theme but is an attempt to focus on the most interesting aspects of the case, which have not yet received sufficient cross-light in the research literature, through the position of one of the leading Russian religious philosophers, priest Pavel Florensky. Here we would like to point out some interesting reasoning provided by S.A. Nizhnikov in his numerous publications, which is distinguishing the all-encompassing task of Russian philosophy as the formation of the faith metaphysics $[1,2]$. Such position is similar to ours with one clarification in connection with the stated topic of the article: the Russian religious philosophy justifies the metaphysics of faith at the expense of reason; Kant finds the opportunity to build a new (in comparison with the ancient and medieval) metaphysics of reason at the expense of faith [3].

The Russian religious philosophers met and saw in Kant

\footnotetext{
*The publication was supported by the Ministry of Education and Science of the Russian Federation (the Agreement number 02.A03.21.0008)
}

not just assertion of power of reason as opposed to faith, but the assertion of power of reason at the expense of faith. Religious consciousness had encountered the first statement from its day of origin: ancient wisdom. In the early Middle Ages, there were already three basic paradigms of interaction of faith and reason - the paradigm of opposition and the paradigm of interaction in two versions (I believe to know and cognize in order to believe). Kant offers another experience of the interaction: I learn to know faith as well. The religious thinker and the priest in one person was most acutely able to feel the full depth of transformation in relation to the believing mind and its aberration, which inevitably follows such a transformation.

\section{FLORENSKY VS. KANT}

On the one hand, the theme of Florensky's relationship to Kant and Kantianism seems to be a particular topic concerning the Russian thinker's attitude to one of the authoritative contemporary Western philosophical trends. On the other hand, it is clear to anyone who is at least familiar with Florensky's work that this topic is no less central than the themes "Florensky and Platonism" or "Florensky and Christianity". What is opposed for Florensky to the religious, which Platonism and Christianity embody, is Kantianism.

Wherefore is Florensky calling Kant the "Pillar of Evil God-Resistant"? We assume this is a very accurate definition of a religious person in reference to the one who placed his faith in the service of the cunning of reason, having dried it with his cunning of proofs, those characteristics of his ultimate concepts and judgments that are inherent in sacral, holy things, having replaced the concepts of faith with the concepts of reason. Perhaps it is difficult to name another such philosopher who could so cleverly use faith in its rationalization. Actually, the whole power of Kant's philosophizing stems from the fact that he had strengthened his mind with all his power of faith. If we talk about the consistency of reason and faith, science and religion in the context of rational philosophy rather than in the context of theological apologetics, it was the great German thinker who fully and most strongly confirmed this position. In fact, he does not mention anywhere the contradiction of faith and reason, only within the mind, "the religion within the limits of reason alone." Many philosophers agreed with such approach before and after Kant, but we believe no one was 
able to use the faith as Kant did. This echoes the evil Angel's action towards ancestors of the human race and the abandoned man.

Florensky has an understanding of Kant's genius, for the system of thought, determined to put itself in the place of God and replace the God-centeredness of Christianity with the self-centeredness, and achieved its goal, could not be not brilliant. Downplaying Kant, Florensky thereby would have pressed Christianity itself.

In his philosophy of the Cult Florensky gives the deepest and at the same time the most detailed description of Kantianism in comparison with Platonism. Several modifications of a number of parallels and introduced new ones, the one can define the core clashes of the positions of Florensky and Kant:

- About. P. Florensky-dogmatism, cultocentrism, antinomicity, medieval (asceticism), Platonic idealism (idea),

- I. Kant-criticism, cultism and idol centrism (Protestantism), contradiction (referring to the inner contradiction of the Kantian philosophical system), Renaissance (humanism), transcendental idealism (autonomy).

According to Florensky, Kant is genius and dangerous at the same time since he became the spokesperson for the worldview that after the Middle Ages only gained strength until several centuries later it turned into the dominant, at least in the Western world. He became as such in the most insidious way - by abolishing the whole epoch, Middle Ages, taking advantage, however, of its luggage but substituting its fundamentals. Everything that Kant avoids and criticizes is immanently present in his philosophical system. For instance, his criticism of dogmatism as a structure of thought based on undefined metaphysical principles. The entire philosophical system of Kant's transcendental idealism is being impregnated with dogmatism. The complexity of Kant's criticism is not in its contradiction, it is obvious and constantly stressed, and in fact criticized, overcome, etc., but in how he himself, realizing the inevitability of the subsequent criticism, strives to avoid his inconsistency. The most sly and dishonest way, according to Florensky — stating he will apply the past centuries' terminology, however, in another sense, based on experience (even Kant tries to interpret this in his own way, having deprived this experience of historical measurement) of the cognitive process, the knowledge of science, calling the latter the mathematical natural science.

The complexity of Kant's criticism is explained by the universality of his philosophical system; actual criticism could only be universal. Florensky took up this task and accomplished it owing to the universality of his approach, demonstrating the naturalness after the antiquity of Plato's medieval Christianity and the artificiality of the Renaissance humanism, which Kant's philosophy crowns.

\section{FLORENSKY VS. KANT-IDEALISM AND PLATONISM}

The complexity of Kant's criticism lies also in the fact that both positions of Florensky and Kant had stemmed from one root - the idealism, which, according to the Russian philosopher, presents the vital worldview. "Philosophy," he emphasizes, "is essentially nothing more but comprehension, the comprehension of an intelligent, sublime, pre-heaven, transcendent world; yet, we know this world," clarifies the philosopher further, "only as a cult, as an embodiment of the upper world in our concrete symbols. Philosophy is, therefore, IDEALISM, not by thoughts occupied, but by a concrete contemplation and experience of intelligent entities, i.e. Cult" [4]. The religious essence of this vital philosophy was more brilliant than any other and was introduced by Plato, whom some philosophers and theologians living in the first centuries of Christianity attributed to thinkers equal to prophets, just as the latter foresaw the emergence of the Christian Revelation and implied in their works the coming of the Savior.

However, insofar as Kant "overcomes" Plato's religiousness by replacing idealism with transcendentalism, putting it on the place of the transcendental subject "ideas" not related to a concrete person, Florensky tries to stay on the side of Plato's position concerning the idealism, giving a detailed type of a "concrete idealism", which cannot be just Christian after the historical appearance of Christ.

A small transformation of idealism-from the Platonic objective to the Kantian subjective- immediately transforms idealism into a closed for experience outside of us, for the reality outside of us, for existing outside of us, for truth outside of us, hence depriving a man of God. Such subjective idealism is serviced by the evolutionism in biology, the mechanistic physics and humanism in the humanities. The contemporary well-known researcher A.I. Osipov emphasizes an even more subtle distinction between the truly religious and the "Kantian" approach to the world and man, relying again on Kant's criticism of Florensky. He writes, "The substitution of morality for morality and of spirituality by morality is a profound error of Kant and all the "Kantians". The fulfillment of moral duties without God is tantamount to the sailing of a ship "without a rudder and sails" [5].

According to Fr. Pavel Florensky, "Platonism turned out to be the philosophy the most suitable to religion, and the terminology of Platonism offers the language most adapted for the expression of religious life. Being the natural philosophy of all religion, however, Platonism has a special affinity with the religion, to which all others barely retain the name of religion" [6]. Another outstanding interpreter A. Losev rightly points out the excessive spiritualization of Platonic ideas by Florensky [6].

Of course, the evaluations of authoritative researchers of ancient philosophy should be taken into account, we can agree with certain subjectivity in reading Plato by Florensky, but the same can be said about any independently-minded philosopher with own concept. Florensky and Losev are among such. This is why their assessments of Plato cannot coincide. 
Florensky's evaluation of Kant, rather than of Plato, is important here-we have the deepest and most authoritative inquiry in the history of philosophy. Let this criticism not be comprehensive, not so concentrated and consistent as in the numerous special studies of various anthologists, followers and subversives of the German philosophical genius, but, we dare say, Kant's philosophical position has never received such a universal and, at the same time, profound rebuff.

Evidence for this present the grounds whereon this criticism of Florensky is carried out. First, there are two large interrelated grounds: historical and informative. Florensky is considering Kant's position universally, all-embracive. This does not mean at all that he is consistently analyzing all the critics of the German philosopher, building his own assessments on them. Certainly not. He considers the Kantian system to be quite logical and consistent in its constructions, having a definite source, wherefrom everything is unfolding. This is epistemology. Science, especially astronomy, according to Florensky, has already demonstrated in modern times the possibility of denying or ignoring the existence of God. It was necessary to show this possibility is not a particular case, but the only verily genuine scientific method. Otherwise, what the Renaissance and innovative science thought, that is, to use its intelligence, a person cannot do.

The Russian philosopher assumes Kant's "merit" is that he had presented how the knowledge could be possible in one and only way. Let us clarify Florensky's insightful conception - Kant both succeeded in examining in detail how the human thinking works and in convincingly demonstrating that it cannot operate otherwise. For this, Kant needed in fact to demonstrate the absolute falsity of other (religious) thinking, while also to use religious terminology and religious characteristics of thinking. As if he says, "You see that I'm not alien to the religious worldview, I even try to think within it (which is correct). After all, it's also an ordinary human thinking and works by the same rules, but no matter how I tried, it is impossible to think antireligiously". The last conclusion in such a radical version was drawn for Kant by the subsequent Western philosophy and civilization.

Florensky was particularly outraged by the following two tenets of Kant's idea - the affirmation of the only possibility to think correctly, that is, to dispose of reason, and the application of the religious terminology themes and characteristics while describing this very mind. Naturally, such utilization could not but be an "artificial camouflage" hiding the German philosopher's true intent. Be that as it may, these artificiality and deliberately hidden aberration contains the compulsion and contradiction, and partially intuitive religious insights, which he could not get rid of. In particular, Florensky points to the importance of the reveal by Kant of "sinfulness as a propensity for sin", as well as his doctrine of antinomy. He highlights there are fractions in our minds that rationalism itself is decomposed. He found out that contradictions are the vitality of human thought rather than are a sign of weakness" [7].

Florensky refutes the uniqueness of thinking by the willful beginning of thinking itself. On his own question where does the presumption of Kant about no Reason outside reason and no Logos outside our own Logos, stems from, the Russian philosopher gives the following answer: "The presumption is from will-the will to be alone, the will to autonomy and to the ontological independence. "There is no mind outside of me," for if it were, as external to me, it would be compulsory for me, it would deprive me of autonomy - that is Kant's slogan. And, therefore, in his mind, he prefers to introduce a subjectively random, not just to subordinate it to the objective-necessary. Not the mind of Truth, but the truth from the mind, not me in Truth, but the truth in me. That is the understanding of orientation, Florensky concludes framing Kant's idea" [8].

\section{FLORENSKY VS. KANT-THE DOCTRINE OF ANTINOMIES}

Florensky demonstrates the brilliance of Kant's obviously subjective incorrect decisions, especially with regard to describing those antinomies. Kant touches on the problem of the antinomy of human mind. "The fabric of Reason," affirms Florensky, "woven by the finitude and infinity - ill infinity, unlimitedness - is beset with differences. Reason equally requires both norms and cannot work without either of them-without the beginning of the finitude and the beginning of the infinity. It cannot work, however, applying both of them since they are incompatibles. The norms of Reason are necessary but they are impossible. Reason turns out to be utterly antinomian in its finest structure" [9].

However, as already mentioned, Kant admits such association in his evidence of cosmological antinomy that calls into question his entire thought system. The Russian philosopher confines himself, as he writes, "to two-three remarks" concerning Kant, and actually makes four observations with the "the rejection of the idea of actual infinity" as the key one [10]. In his remarks to the publication of Florensky's work, A.T. Kazaryan turns attention to the questionable value of this remark in view of the fact that Florensky borrows the idea of actual infinity from Cantor who has a distinguished from Kant perception of the intuition [11]. If we accept the domestic researcher's objection, then only in the part of the sequence or inconsistency of Kant. As for the subjective "orientation"the choice of the thinking principles - this divergence between Kant and Cantor clearly substantiates Florensky's keynote about the willful beginning of thinking and the subjective nature of choosing a priori principles.

\section{CONCLUSION}

Kant presents the central figure, a counterpoint to the idea of Florensky. Even his main work "The Pillar and Ground of the Truth" the Russian religious philosopher writes at the same time in refutation and in the development of the German philosopher's insight. Whereas Kant answers the question "What can I know?", in other words "How is the thinking possible?", his Russian counterpart raises the issue more radically "How is the knowledge possible at all?", that is to say "How is the very mind possible?". Whereas Kant, 
through the antinomy, "just opens slightly the door behind the scenes of the mind" and therefore prefers to remain in a purely subjective sphere of consciousness, Florensky boldly goes into this "backstage of reason" to open an objective truth that the subject does not own, but which owns the subject.

In his criticism of Kant, the Russian philosopher deliberately prefers the religious and philosophical position rather than the theological (in contrast to S. Bulgakov). It was important for Florensky to show the mind's natural possibility to be different, rather than attributed to it by the philosophers of the Kantian tradition.

Criticism of Kant aims to present Florensky's own position. This position helped to integrate criticism into the philosophical tradition that became, in the original religious interpretation of the Russian philosopher, the development of Platonism, and to test lectures on the occupation of the post of associate professor at the Department of Philosophy of the Moscow Theological Academy in September 1908. P. Florensky read lectures "Human Roots of Idealism", dedicated to the philosophy of Plato, and "Cosmological antinomies of Kant".

Among the most consistent successors of the Kantian philosophy - neo-Kantians - Florensky frequently mentions G. Cohen who headed the Marburg school, which is no coincidence. Cohen focused his efforts on building the philosophical system in consequence of the development of the Kantian theory of knowledge, which was precisely the target of Florensky's criticism. In addition, the Marburg philosopher, inspired by Kant's transcendentalism, very accurately diagnoses the contradictory moments of the Kantian system and shows in what direction, proceeding from the spirit of Kantian philosophy, they must be corrected. More importantly, at the outset of the $20^{\text {th }}$ century, the Marburg Neo-Kantianism, headed by G. Cohen, formed a very definite philosophical school, which enabled Florensky to address Cohen as the representative of an integral philosophical concept. However, it should be acknowledged that such address had been occasional, in order to demonstrate the validity of Kant's own critical evaluation of philosophy.

\section{REFERENCES}

[1] A.S. Losev, Essays on ancient symbolism and mythology, M., 1930.

[2] S.A. Nizhnikov, Metaphysics of faith in Russian philosophy, M., 2001.

[3] V.N. Belov, V.P. Rozhkov, History of Russian philosophy, Saratov, 2006, pp. 225-226.

[4] P.A. Florensky, Collected works, Cult Philosophy (An experience of Orthodox anthropodice). M., 2004, p.109.

[5] A.I. Osipov, The way of the mind in search of truth. Basic theology. M., 2010, p. 41.

[6] A.S. Losev, Essays on ancient symbolism and mythology, M., 1930, p.692.

[7] P.A. Florensky, About orientation in philosophy (philosophy and livelihood) // Florensky P.A., Collected works in 4 volumes. Vol. 3 (2), M., 2000, p. 405.
[8] P.A. Florensky, Collected works, Cult philosophy (Experience of the Orthodox anthropodice). M., 2004, p.112.

[9] P.A. Florensky, The Pillar and Ground of the Truth. T. 1. M., 1990, p. 487.

[10] P.A. Florensky, Cosmological antinomies of Immanuel Kant // Florensky P.A., Collected works in four volumes, Vol. 2, M., 1996, p. 27.

[11] Ibid, p. 734. 